\title{
Increased responsiveness to glucoregulatory effect of opiates in obese-diabetic ob/ob mice
}

\author{
C.J. Bailey ${ }^{1}$ and P.R. Flatt ${ }^{2}$ \\ ${ }^{1}$ Department of Molecular Sciences, Aston University, Birmingham and ${ }^{2}$ Department of Biochemistry, University of Surrey, Guildford, UK
}

\begin{abstract}
Summary. Plasma glucose and insulin responses to opiate receptor stimulation and antagonism were determined in 12-14 week old lean and obese-diabetic Aston ob/ob mice. The opiate receptor antagonist naloxone $(1 \mathrm{mg} / \mathrm{kg}$ intraperitoneally) rapidly and transiently raised glucose and suppressed insulin concentrations in lean mice, and produced qualitatively similar but more protracted responses in ob/ob mice. Selective stimulation of $\mu$ - and $\delta$-opiate receptors using the enkephalin analogues Tyr-D-Ala-Gly-MePhe- $\mathrm{NH}\left(\mathrm{CH}_{2}\right)_{2} \mathrm{OH}$ $(1 \mathrm{mg} / \mathrm{kg}$, intraperitoneally) and Tyr-D-Ala-Gly-Phe-D-Leu $(10 \mathrm{mg} / \mathrm{kg}$ intraperitoneally) respectively, rapidly and tran-
\end{abstract}

siently increased glucose and insulin concentrations in lean and $\mathrm{ob} / \mathrm{ob}$ mice. The ob/ob mice exhibited greater glucose and insulin responses to these analogues. The results (1) provide evidence that endogenous opiates participate in the regulation of glucose and insulin homeostasis, and (2) suggest that increased responsiveness to $\mu$ - and $\delta$-opiate receptor stimulation may contribute to the hyperglycaemia and hyperinsulinaemia of obese-diabetic mice.

Key words: Opiates, enkephalin analogues, naloxone, obesediabetic ob/ob mice, glucose, insulin.
Several studies have suggested that opiate peptides might contribute to the regulation of glucose homeostasis. Morphine and B-endorphin produce a hyperglycaemic effect [1-5], and stimulate insulin release from isolated pancreatic islets [6-10]. Dynorphin, met- and leu-enkephalin and enkephalin analogues with opiate agonist properties also stimulate insulin release in vitro, and this effect is inhibited by the opiate antagonist naloxone [7,9-11]. The possible physiological relevance of these observations is brought into focus by the identification of opiate peptides within cells of the pancreatic islets and within the nervous innervation of the pancreas [12-17]. However, studies on the effects of opiates in vivo have been hampered by a lack of stable analogues with selective agonist effects at different subtypes of opiate receptors.

Using naloxone and enkephalin analogues, evidence has emerged to suggest that abnormal responses to endogenous opiates may be a factor in the development of hyperglycaemia and defective insulin secretion in human Type 2 (non-insulin-dependent) diabetes mellitus [18-20].

The obese hyperglycaemic (ob/ob) mouse has been used extensively as a model of non-insulin-dependent diabetes mellitus, being characterised by gross obesity, hyperphagia, moderate hyperglycaemia, marked hyperinsulinaemia and severe insulin resistance [21-24]. The present study was undertaken to investigate the effect of opiates on normal glucose and insulin homeostasis, and to examine the possibility that abnormal responses to opiates contribute to the hyperglycaemia and hyperinsulinaemia of ob/ob mice. Acute changes in plasma glucose and insulin concentrations were determined in lean and ob/ob mice after administration of naloxone and stable enkephalin analogues with selective agonist properties at $\mu$ and $\delta$-opiate receptors.

\section{Materials and methods}

\section{Animals}

Obese hyperglycaemic (ob/ob) mice and homozygous lean $(+/+)$ mice from the colony maintained at Aston University, Birmingham, UK were used at 12-14 weeks of age. The origin and characteristics of these mice have been described previously [23, 25]. Mice were housed in an air conditioned room at $22 \pm 2^{\circ} \mathrm{C}$ with a lighting schedule of $12 \mathrm{~h}$ light (08.00-20.00 hours) and $12 \mathrm{~h}$ dark. A standard pellet diet (Mouse breeding diet, Heygate \& Sons, Northampton, UK) and tap water were supplied ad libitum.

\section{Chemicals}

The chemicals and their sources were: naloxone hydrochloride (batch 64F-0209) from Sigma Chemical Company, Poole, UK; Tyr-D-AlaGly-MePhe-NH( $\left.\mathrm{CH}_{2}\right)_{2} \mathrm{OH}$ (batch 11064) and Tyr-D-Ala-Gly-Phe-DLeu (batch 23114) from Cambridge Research Biochemicals, Cambridge, UK. Other chemicals and reagents were obtained as previously [26]. Whereas naloxone is an antagonist of all known subtypes of opiate receptors, with an especially potent effect at $\mu$-opiate receptors, the enkephalin analogues Tyr-D-Ala-Gly-MePhe$\mathrm{NH}\left(\mathrm{CH}_{2}\right)_{2} \mathrm{OH}$ and Tyr-D-Ala-Phe-Gly-D-Leu are predominantly 
Table 1. Characteristics of animals: body weights and plasma concentrations of glucose and insulin in fed and $24 \mathrm{~h}$ fasted lean $(+/+)$ and obese (ob/ob) mice. Values are means \pm SEM. Numbers of mice are shown in parentheses

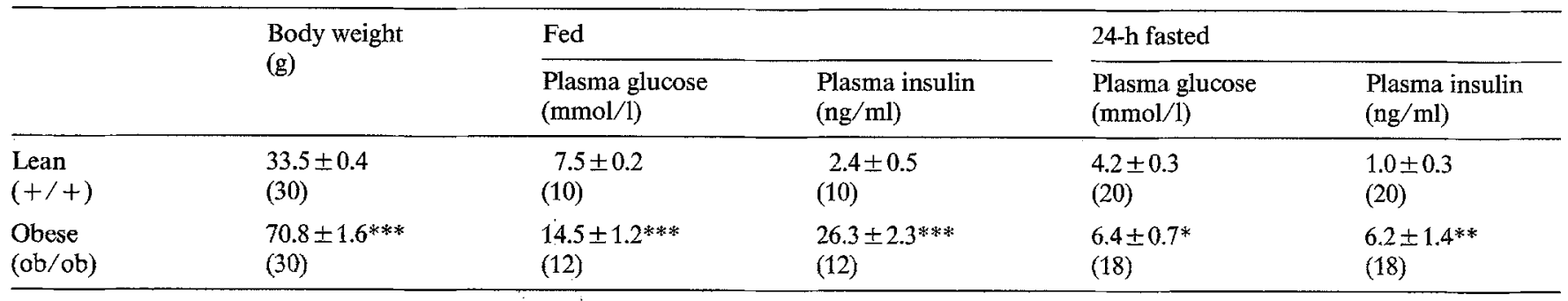

${ }^{*} p<0.02, * * p<0.01, * * * p<0.001$ compared with lean $(+/+)$ mice

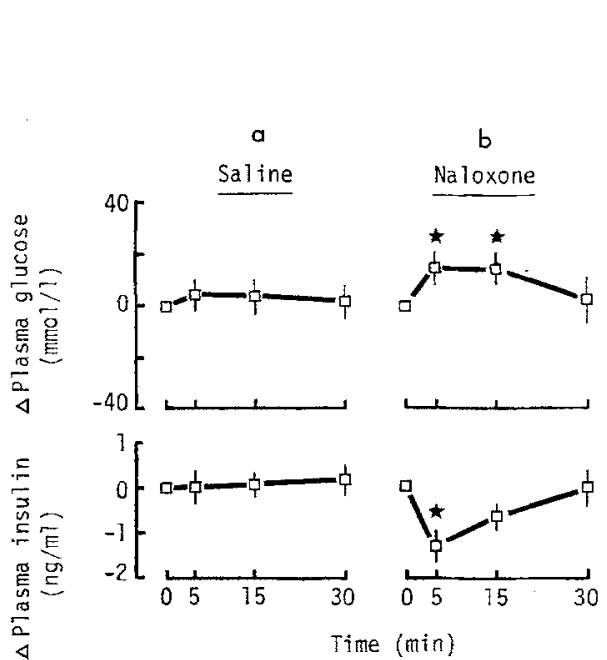

Fig. 1. Changes $(\Delta)$ in plasma glucose and insulin concentrations of 12-14 week old fed lean Aston mice after intraperitoneal administratio of saline $(5 \mathrm{ml} / \mathrm{kg})$ and naloxone hydrochloride $(1 \mathrm{mg} / \mathrm{kg})$. Values are mean \pm SEM of 5 mice. ${ }^{*} p<0.05$ compared with time zero

agonists at $\mu$ - and $\delta$-opiate receptors, respectively, and show a high degree of stability when administered in vivo $[27,28]$.

\section{Experimental procedure}

Test substances were dissolved in saline $(0.9 \% \mathrm{NaCl})$ and administered by intraperitoneal (ip) injection to groups of lean and ob/ob mice. Naloxone $(1 \mathrm{mg} / \mathrm{kg})$ or saline $(5 \mathrm{ml} / \mathrm{kg})$ was administerd to fed lean and $\mathrm{ob} / \mathrm{ob}$ mice, and Tyr-D-Ala-Gly-MePhe- $\mathrm{NH}\left(\mathrm{CH}_{2}\right)_{2} \mathrm{OH}$ (1 $\mathrm{mg} / \mathrm{kg}$ ), Tyr-D-Ala-Gly-Phe-D-Leu ( 1 and $10 \mathrm{mg} / \mathrm{kg}$ ) or saline $(5 \mathrm{ml} / \mathrm{kg})$ was administered to $24 \mathrm{~h}$ fasted lean and ob/ob mice. Blood samples $(60 \mu \mathrm{l})$ for plasma glucose and insulin determination were taken from the tail tip of conscious mice immediately before and at 5 , 15 and $30 \mathrm{~min}$ after the injection of test substances. In an additional study with $24 \mathrm{~h}$ fasted lean mice, ip injections of Tyr-D-Ala-MePhe$\mathrm{NH}\left(\mathrm{CH}_{2}\right)_{2} \mathrm{OH}(1 \mathrm{mg} / \mathrm{kg})$ and Tyr-D-Ala-Gly-Phe-D-Leu $(10 \mathrm{mg} / \mathrm{kg})$ were given $20 \mathrm{~min}$ after an ip injection of glucose $(1 \mathrm{~g} / \mathrm{kg})$, and blood samples were taken immediately before and at 5 and $15 \mathrm{~min}$ after the injections of opiates. Food, but not water, was withheld during all tests. The mice were adapted to the manipulative procedures for $2-3$ weeks before study to obviate any stress response [26]. The doses of opiates used must be regarded as pharmacological. They were selected after a preliminary study to identify the amounts required to produce measurable changes in plasma glucose and insulin after ip injection into lean mice.

\section{Statistical analysis}

Plasma glucose was measured by an automated glucose oxidase procedure, and plasma insulin was determined by double antibody

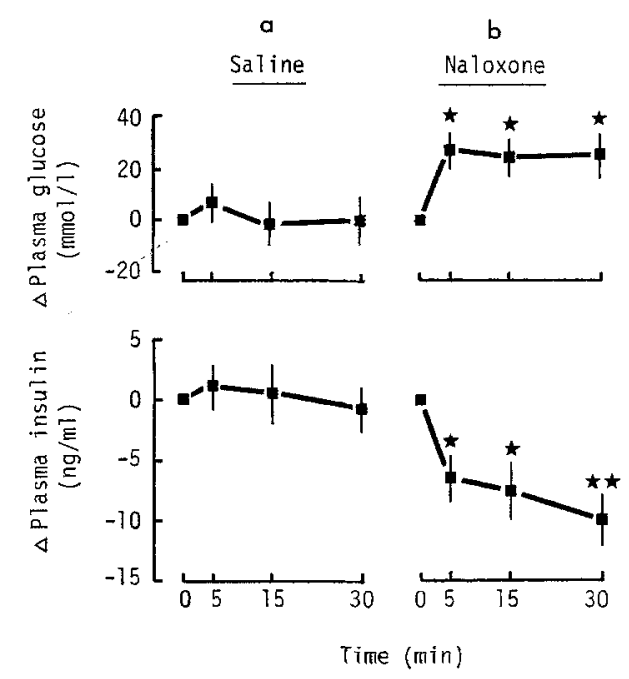

Fig. 2. Changes $(\Delta)$ in plasma glucose and insulin concentrations of 12-14 week old fed obese-diabetic Aston ob/ob mice after intraperitoneal administration of saline $(5 \mathrm{ml} / \mathrm{kg})$ and naloxone hydrochloride $(1 \mathrm{mg} / \mathrm{kg})$. Values are mean $\pm \mathrm{SEM}$ of 6 mice. ${ }^{*} p<0.05, * * p<0.01$ compared with time zero

radioimmunoassay as described previously [29]. Data are expressed in the figures as the change in plasma glucose (mmol/l) or insulin (ng/ $\mathrm{ml}$ ) compared with time zero. $\Sigma$ values cited in the text refer to the sum of changes in plasma glucose $(\mathrm{mmol} / \mathrm{l})$ or insulin $(\mathrm{ng} / \mathrm{ml})$ at 5,15 , and $30 \mathrm{~min}$, i. e. sum of values at 5,15 and $30 \mathrm{~min}$ minus 3 times the value at time zero. All values are means $\pm S E M$ of 5 lean and $6 \mathrm{ob} / \mathrm{ob}$ mice. Groups of data from the same mice were compared using Student's paired t-test, and groups of data from different mice were compared using Student's unpaired t-test. Differences were considered to be significant if $p<0.05$.

\section{Results}

The ob/ob mice were characteristically obese, as indicated by their greater body weight, and exhibited a typically moderate hyperglycaemia and marked hyperinsulinaemia in the fed and fasted state (Table 1).

Administration of saline $(5 \mathrm{ml} / \mathrm{kg})$ did not significantly alter plasma glucose or insulin concentrations in either fed (Figs. $1 \mathrm{a}$ and $2 \mathrm{a}$ ) or 24 -h fasted (Figs. $3 \mathrm{a}$ and 4 a) lean and ob/ob mice during the $30 \mathrm{~min}$ period of study. In fed lean mice, naloxone $(1 \mathrm{mg} / \mathrm{kg})$ produced a rapid, small and transient rise in plasma glucose $(\Sigma+2.2 \pm 0.5 \mathrm{mmol} / \mathrm{l})$ accompanied by a rapid and transient fall in plasma insulin $(\Sigma-1.8 \pm 0.6 \mathrm{ng} / \mathrm{ml})$ (Fig. 1b). In fed ob/ob mice naloxone produced a more protracted rise in plasma glucose $(\Sigma+4.3 \pm 0.6 \mathrm{mmol} / 1$; 


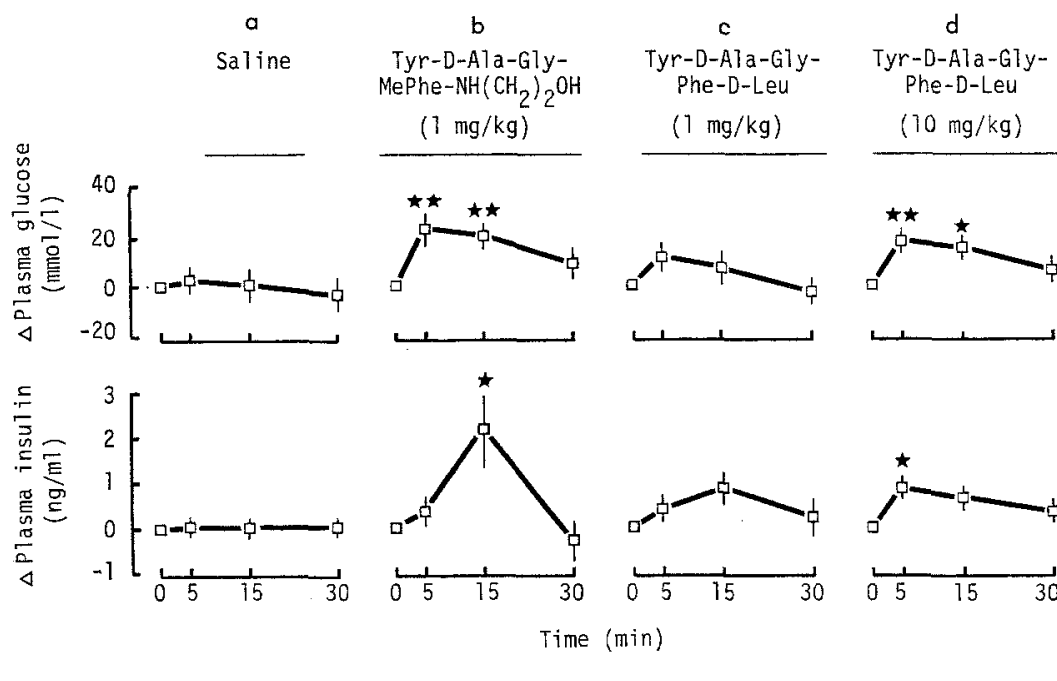

Fig. 3. Changes $(\Delta)$ in plasma glucose and insulin concentrations of $12-14$ week old $24 \mathrm{~h}$ fasted lean Aston mice after intraperitoneal administration of saline (5 ml/kg), Tyr-D-Ala-Gly-MePhe- $\mathrm{NH}\left(\mathrm{CH}_{2}\right)_{2} \mathrm{OH}$ $(1 \mathrm{mg} / \mathrm{kg})$ and Tyr-D-Ala-Gly-Phe-D-Leu (1 and $10 \mathrm{mg} / \mathrm{kg}$ ). Values are mean \pm SEM of 5 mice. ${ }^{*} p<0.05,{ }^{* *} p<0.01$ compared with time zero

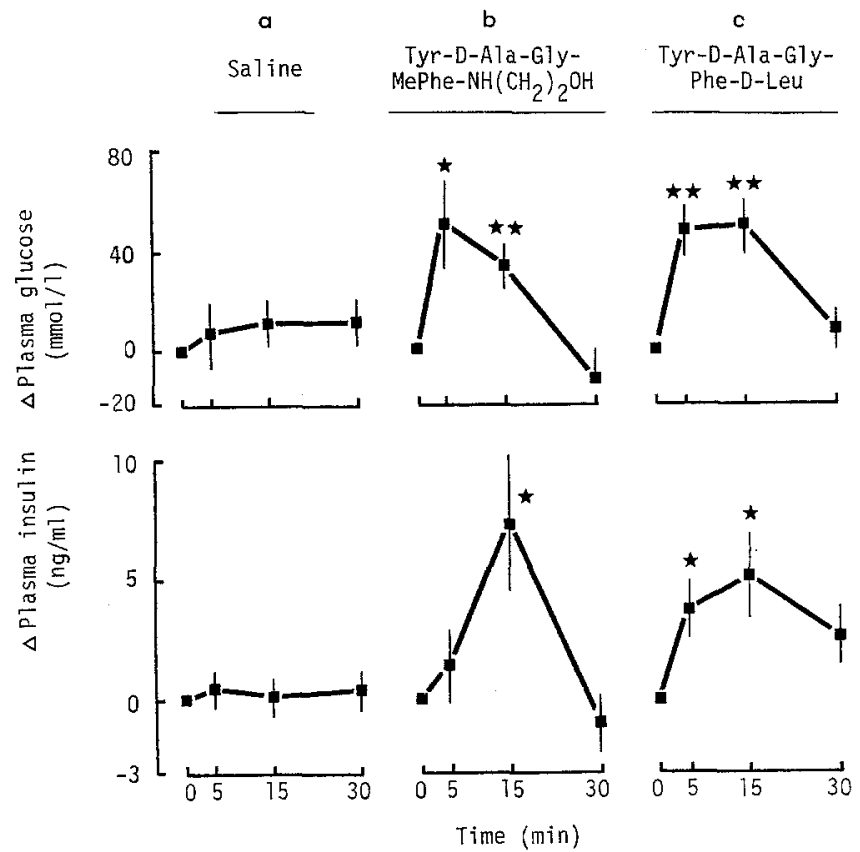

Fig. 4. Changes $(\Delta)$ in plasma glucose and insulin concentrations of 12-14 week old 24-h fasted obese-diabetic Aston ob/ob mice after intraperitoneal injection of saline $(5 \mathrm{mg} / \mathrm{kg})$, Tyr-D-Ala-Gly-MePhe$\mathrm{NH}\left(\mathrm{CH}_{2}\right)_{2} \mathrm{OH}(1 \mathrm{mg} / \mathrm{kg})$ and Tyr-D-Ala-Gly-Phe-D-Leu $(1 \mathrm{mg} / \mathrm{kg})$. Values are mean $\pm S E M$ of 6 mice. ${ }^{*} p<0.05,{ }^{* *} p<0.01$ compared with time zero

$p<0.05$ compared with fed lean mice) and a more sustained fall in plasma insulin $(\Sigma-23.5 \pm 3.5 \mathrm{ng} / \mathrm{ml} ; p<$ 0.001 compared with fed lean mice) (Fig. 2 b).

Fasted lean mice responded to Tyr-D-Ala-GlyMePhe- $\mathrm{NH}\left(\mathrm{CH}_{2}\right)_{2} \mathrm{OH}(1 \mathrm{mg} / \mathrm{kg})$ with rapid and transient increases in plasma glucose $(\Sigma+2.8 \pm 0.6 \mathrm{mmol} / \mathrm{l})$ and insulin $(\Sigma+2.2 \pm 1.1 \mathrm{ng} / \mathrm{ml})$ (Fig. $3 \mathrm{~b})$. Tyr-D-AlaGly-Phe-D-Leu did not significantly alter either plasma glucose $(\Sigma+0.5 \pm 0.7 \mathrm{mmol} / \mathrm{l})$ or insulin $(\Sigma+1.2 \pm$ $0.8 \mathrm{ng} / \mathrm{ml}$ ) at a dose of $1 \mathrm{mg} / \mathrm{kg}$, but a higher dose of this analogue $(10 \mathrm{mg} / \mathrm{kg})$ elevated both plasma glucose $(\Sigma+2.0 \pm 0.4 \mathrm{mmol} / \mathrm{l})$ and insulin $(\Sigma+1.45 \pm 0.3$ $\mathrm{ng} / \mathrm{ml}$ ) in a rapid and transient manner (Fig. 3c, d). In fasted $o b / o b$ mice both Tyr-D-Ala-Gly-MePhe-

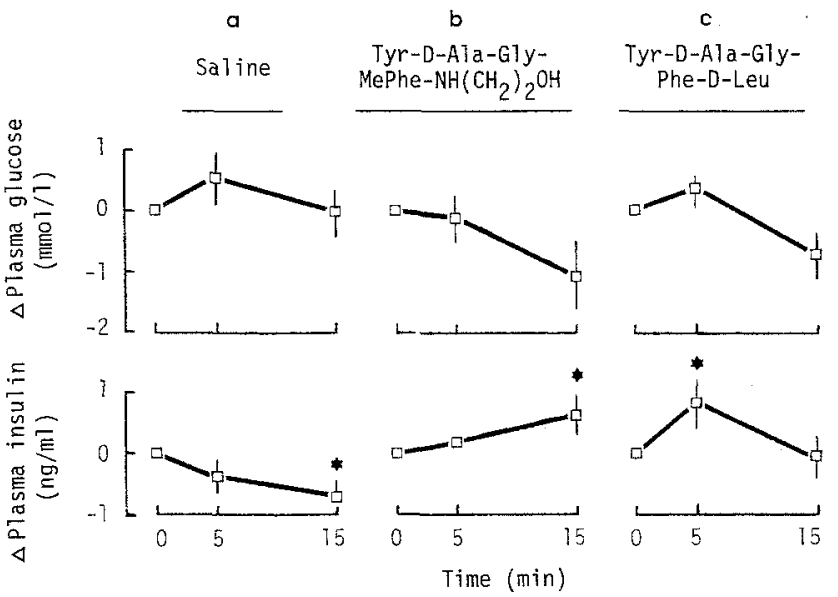

Fig.5. Changes $(\Delta)$ in plasma glucose and insulin concentrations of 12-14 week old 24-h fasted lean Aston mice after intraperitoneal injection of glucose $(1 \mathrm{~g} / \mathrm{kg})$ at time $-20 \mathrm{~min}$, and intraperitoneal injection of either saline $(5 \mathrm{ml} / \mathrm{kg})$, Tyr-D-Ala-Gly-MePhe- $\mathrm{NH}\left(\mathrm{CH}_{2}\right)_{2} \mathrm{OH}$ $(1 \mathrm{mg} / 1 \mathrm{~g})$ or Tyr-D-Ala-Gly-Phe-D-Leu $(10 \mathrm{mg} / \mathrm{kg})$ at time zero. Values are mean \pm SEM of 5 mice. ${ }^{*} p<0.05$ compared with time zero

$\mathrm{NH}\left(\mathrm{CH}_{2}\right)_{2} \mathrm{OH}(1 \mathrm{mg} / \mathrm{kg})$ and Tyr-D-Ala-Gly-Phe-DLeu $(1 \mathrm{mg} / \mathrm{kg})$ produced rapid transient increases in plasma glucose $(\Sigma+3.9 \pm 1.0$ and $+5.7 \pm 0.5 \mathrm{mmol} / 1 \mathrm{re}$ spectively) and insulin $(\Sigma+7.1 \pm 1.4$ and $+11.4 \pm$ $2.5 \mathrm{ng} / \mathrm{ml}$ respectively) (Fig. 4b, c). Compared with lean mice, ob/ob mice exhibited a greater insulin response to Tyr-D-Ala-Gly-MePhe- $\mathrm{NH}\left(\mathrm{CH}_{2}\right)_{2} \mathrm{OH}(p<0.05)$ and greater glucose and insulin responses to Tyr-D-Ala-GlyPhe-D-Leu ( $p<0.01$ and $p<0.001$ respectively).

To investigate whether the greater insulin responses to the opiate analogues in $\mathrm{ob} / \mathrm{ob}$ mice were facilitated by the higher fasting glucose concentrations, the opiate analogues were administered to fasted lean mice after elevation of plasma glucose by prior administration of glucose ( $1 \mathrm{~g} / \mathrm{kg}$ ip, $20 \mathrm{~min}$ previously). After glucose ad-

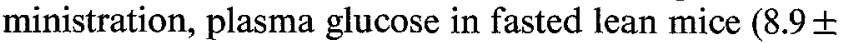
$0.5 \mathrm{mmol} / 1, n=15)$ was higher than in untreated fasted lean mice $(4.2 \pm 0.3 \mathrm{mmol} / 1, n=20, p<0.001)$ and fasted ob/ob mice $(6.4 \pm 0.7 \mathrm{mmol} / 1, n=18, p<0.01)$. In mice treated with saline $(5 \mathrm{ml} / \mathrm{kg})$ plasma glucose con- 
centrations were unchanged at 5 and $15 \mathrm{~min}$, whereas plasma insulin was decreased by $0.66 \pm 0.34 \mathrm{ng} / \mathrm{ml}$ $(\mathrm{n}=5)$ at $15 \mathrm{~min}$ (Fig. $5 \mathrm{a})$. Neither Tyr-D-Ala-GlyMePhe- $\mathrm{NH}\left(\mathrm{CH}_{2}\right)_{2} \mathrm{OH}(1 \mathrm{mg} / \mathrm{kg})$ nor Tyr-D-Ala-GlyPhe-D-Leu $(10 \mathrm{mg} / \mathrm{kg})$ significantly altered plasma glucose (Fig. 5b, c). However, Tyr-D-Ala-Gly-MePhe$\mathrm{NH}\left(\mathrm{CH}_{2}\right)_{2} \mathrm{OH}$ increased insulin concentrations by $0.61 \pm 0.33 \mathrm{ng} / \mathrm{ml}(n=5, p<0.05$ compared with saline) at $15 \mathrm{~min}$, and Tyr-D-Ala-Gly-Phe-D-Leu increased insulin concentrations by $0.82 \pm 0.45 \mathrm{ng} / \mathrm{ml} \quad(n=5$, $p<0.05$ compared with saline) at $5 \mathrm{~min}$. These insulin responses to the opiate analogues were considerably less than those observed in ob/ob mice (Fig. $4 b, c$ ).

\section{Discussion}

The transient hyperglycaemia and hypoinsulinaemia observed after opiate receptor antagonism with naloxone in lean mice indicate that endogenous opiate-mediated mechanisms participate in the normal control of glucose homeostasis. In particular it appears that endogenous opiates directly promote insulin secretion, as indicated by previous in vitro studies [6-11]. This view is substantiated herein by in vivo administration of the selective and stable enkephalin analogues Tyr-D-Ala-GlyMePhe-NH( $\left(\mathrm{CH}_{2}\right)_{2} \mathrm{OH}$ and Tyr-D-Ala-Gly-Phe-D-Leu, which induced a rapid and transient increase of insulin concentrations. Interestingly, the enkephalin analogues also produced a transient rise in glucose concentrations. This effect may involve an action on glucagon and the central nervous system [3-5], which could contribute to the accompanying hyperinsulinaemia by increasing the glycaemic stimulus for insulin release [30], and by activation of insulinotropic neuroendocrine pathways linking the central nervous system and the pancreatic islets [31]. The transient hyperglycaemia noted after opiate antagonism with naloxone may be consequent in part to the concomitant decrease of insulin concentrations. However, it would not seem unreasonable to surmise that the widespread distribution of endogenous opiates $[32,33]$ might be associated with additional effects on glucose homeostasis to those considered above. Indeed, it has recently been suggested that endogenous opiates influence peripheral glucose uptake by a mechanism that is independent of insulin or major counterregulatory hormones $[34,35]$. The greater responses evoked in lean mice by the $\mu$-opiate agonist (Tyr-D-Ala-GlyMePhe- $\left.\mathrm{NH}\left(\mathrm{CH}_{2}\right)_{2} \mathrm{OH}\right)$ and the $\delta$-opiate agonist (TyrD-Ala-Gly-Phe-D-Leu) might reflect a preponderance or a higher affinity of $\mu$-opiate receptors on the target cells concerned. However, differences in the biological stability and reactivity of these agents could be contributory factors. The responses cannot be attributed to a stress reaction, since saline did not significantly affect glucose and insulin concentrations in this test system, as noted previously [26].

Several observations have indicated abnormalities of opiate production and action in obese-diabetic ob/ ob mice. Thus, ob/ob mice exhibit raised levels of B-endorphin, met ${ }^{5}$-enkephalin and leu $\mathrm{u}^{5}$-enkephalin in the pituitary, hypothalamus and pancreas [36-41]. The ob/ ob mice also show heightened feeding and drinking responses to opiate agonists and antagonists, particularly those acting predominantly at $K$-opiate receptors $[36$, $40,42]$. The present study provides evidence of disturbances in the glucoregulatory effects of opiates in ob/ ob mice. For example, compared with lean mice naloxone produced a more protracted hyperglycaemia and hypoinsulinaemia, and the enkephalin analogues, TyrD-Ala-Gly-MePhe- $\mathrm{NH}\left(\mathrm{CH}_{2}\right)_{2} \mathrm{OH}$ and Tyr-D-Ala-GlyPhe-D-Leu evoked greater responses of glucose and/or insulin. There was also no apparent difference in the glucoregulatory effectiveness of the $\mu$-opiate agonist (Tyr-D-Ala-Gly-MePhe- $\left.\mathrm{NH}\left(\mathrm{CH}_{2}\right)_{2} \mathrm{OH}\right)$ and the $\delta$-opiate agonist (Tyr-D-Ala-Gly-Phe-D-Leu) in the mutant mice. The especially marked reduction of insulin concentrations after naloxone administration, and the enhanced insulin responses to the enkephalin analogues, which do not appear to reflect the elevated glycaemia, support the view that endogenous opiates may act in addition to increased activity of the entero-insular axis $[24,43-45]$ to promote excessive insulin secretion in ob/ ob mice. This role of opiates may reflect increased Bcell sensitivity to these insulinotropic peptides, or increased opiate biosynthesis and release by the pituitary and gastro-intestinal tract of ob/ob mice [36-42, 46]. Since ob/ob mice show a reduced insulin-releasing effect of hyperglycaemia per se $[25,26,47]$, the greater insulin response to opiate agonists in the ob/ob mice is not attributable to the greater rise in glycaemia. The very short half life of endogenous opiates in the peripheral circulation [48] draws attention to the possible significance of recent studies demonstrating that opiate peptides are synthesised and released within the islet [12-15].

Thus, opiates appear to participate in the control of glucose homeostasis through a transient insulinotropic effect involving $\mu$ - and $\delta$-opiate receptors. Opiates can stimulate hyperglycaemia; however, since opiate blockade can also raise glucose concentrations, it is evident that other mechanisms of glucoregulation by opiates must exist. The present study indicates that increased responsiveness to opiates may contribute to the hyperglycaemia and hyperinsulinaemia of obese-diabetic mice.

Acknowledgement. The authors are grateful to Mr. M. Gamble and Ms. C. Ewan for their excellent animal care and technical assistance, and Mr. I. Kitchen for helpful discussions.

\section{References}

1. Feldberg W, Shaligram SV (1972) The hyperglycaemic effect of morphine. Br J Pharmacol 46: 602-618

2. Feldberg W, Gupta KP (1974) Morphine hyperglycaemia. J Physiol 238: 487-502

3. Feldberg W, Smythe DG (1977) C-fragment of lipotropin - an endogenous potent analgesic peptide. Br J Pharmacol 60:445-453 
4. Reid RL, Yen SSC (1981) B-endorphin stimulates the secretion of insulin and glucagon in humans. J Clin Endocrinol Metab 52: 592-594

5. Feldman M, Kiser RS, Unger RH, Li CH (1983) Beta-endorphin and the endocrine pancreas. Studies in healthy and diabetic human beings. N Engl J Med 308: 349-353

6. Ipp E, Dobbs RE, Unger RH (1978) Morphine and B-endorphin influence the secretion of the endocrine pancreas. Nature 276: $190-191$

7. Green IC, Perrin D, Pedley KC, Leslie RDG, Pyke D (1980) Effect of enkephalins and morphine on insulin secretion from isolated rat islets. Diabetologia 19:158-161

8. Sachse G, Laube H, Svedberg J, Breidenbach Th, Teschemaker HJ (1981) Opiates influence endocrine pancreas secretion. Diabetologia 21:322

9. Hermansen K (1982) Opiates and the secretion of the endocrine pancreas in the dog. Diabetologia 23: 174.

10. Hermansen K (1983) Enkephalins and the secretion of pancreatic somatostatin and insulin in the dog: studies in vitro. Endocrinology $113: 1149-1154$

11. Green IC, Perrin D, Penman E, Yaseen A, Ray K, Howell SL (1983) Effect of dynorphin on insulin and somatostatin secretion, calcium uptake, and cAMP levels in isolated rat islets of Langerhans. Diabetes 32: 685-690

12. Grube D, Voight KH, Weber E (1978) Pancreatic glucagon cells contain endorphin like immunoreactivity. Histochemistry 59: $75-79$

13. Bruni JF, Watkins WB, Yen SSC (1979) B-endorphin in the human pancreas. J Clin Endocrinol Metab 49: 649-651

14. Watkins WB, Bruni JF, Yen SSC (1980) B-endorphin and somatostaton in the pancreatic D-cell co-localisation by immunocytochemistry. J Histochem Cytochem 28: 1170-1174

15. Zulke H, Niendorf W-R, Jess G, Hahn von Dorsche H (1985) Evidence for the biosynthesis of B-endorphin in isolated islets of Langerhans. Diab Rec Clin Pract 1 [Suppl 1]: S524

16. Timmers KI, Voyles NR, King C, Wells M, Fairtile R, Recant L (1986) Opioid peptides in rat islets of Langerhans: immunoreactive met- and leu-enkephalins and BAM-22P. Diabetes 35:52-57

17. Larsson LI (1979) Innervation of the pancreas by substance P, enkephalin, vasoactive intestinal polypeptide, and gastrin/CCK immunoreactive nerves. J Histochem Cytochem 27: 1283-1284

18. Leslie RDG, Pyke D, Stubbs WA (1979) Sensitivity to enkephalin as a cause of non-insulin dependent diabetes. Lancet 1: 341-343

19. Giugliano D, Ceriello A, diPinto P, Saccomanno F, Gentile S, Cappoapuoti $F$ (1982) Impaired insulin secretion in human diabetes mellitus. The effect of naloxone-induced opiate receptor blockade. Diabetes 31: 367-370

20. Mason JS, Heber D (1982) Endogenous opiates modulate insulin secretion in flushing non-insulin dependent diabetes. J Clin Endocrinol Metab 54: 693-697

21. Herberg L, Coleman DL (1977) Laboratory animals exhibiting obesity and diabetes syndromes. Metabolism 26: 59-99

22. Bray GA, York DA (1979) Hypothalamic and genetic obesity in experimental animals: an autonomic and endocrine hypothesis. Physiol Rev 59: 719-809

23. Bailey CJ, Flatt PR, Atkins TW (1982) Influence of genetic background on the expression of the obese hyperglycemic syndrome in Aston ob/ob mice. Int J Obes 6: 11-21

24. Bailey CJ, Flatt PR (1986) Animal models of diabetes. In: Nattrass M(ed) Recent advances in diabetes II. Churchill Livingstone, Edinburgh, pp 71-89

25. Flatt PR, Bailey CJ (1981) Abnormal plasma glucose and insulin responses in heterozygous lean $(\mathrm{ob} /+)$ mice. Diabetologia 20: $573-577$

26. Flatt PR, Bailey CJ, Buchanan KD (1982) Regulation of plasma immunoreactive glucagon in obese hyperglycaemic (ob/ob) mice. J Endocrinol 95: 215-227

27. Handa BK, Lane AC, Lord JAH, Morgan BA, Rance MJ, Smith CFC (1981) Analogues of B-LPH ${ }^{61-64}$ possessing selective agonist activity at $\mu$-opiate receptors. Eur J Pharmacol 70: $531-540$
28. Paterson SJ, Robson LE, Kosterlitz HW (1983) Classification of opioid receptors. Br Med Bull 39:31-36

29. Bailey CJ, Ahmed-Sorour HA (1980) Role of ovarian hormones in the longterm control of glucose homeostasis. Effects on insulin secretion. Diabetologia 19:475-481

30. Malaisse WJ (1983) Insulin release: the fuel concept. Diab Metab 9:313-320

31. Szabo AJ (ed) (1983) CNS regulation of carbohydrate metabolism. Adv Metab Dis 10, Academic Press, New York, pp 1-508

32. Cuello AC (1983) Central distribution of opioid peptides. $\mathrm{Br}$ Med Bull 39: 11-16

33. North RA, Egan TM (1983) Actions and distributions of opioid peptides in peripheral tissues. Br Med Bull 39:71-76

34. Werther GA, Jolfe S, Artal R, Sperling MA (1984) Opiates modulate insulin action in vivo in dogs. Diabetologia 26: 65-69

35. Werther GA, Jolfe S, Artal R, Sperling MA (1985) Opiate modulation of glucose turnover in dogs. Metabolism 34: 136-140

36. Margules DL, Moisset B, Lewis MJ, Shibuya H, Pert CB (1978) Bendorphin is associated with overeating in genetically obese mice $(\mathrm{ob} / \mathrm{ob})$ and rats (fa/fa). Science 202: 988-991

37. Rossier JM, Rogers J, Shibasaki T, Guilleman R, Bloom FE (1979) Opioid peptides and $\alpha$-melanocyte stimulating hormone in genetically obese (ob/ob) mice during development. Proc Natl Acad Sci USA 76: 2077-2080

38. Garthwaite TL, Martinson DR, Tseng LF, Hagen TC, Menahan LA (1980) A longitudinal hormonal profile of the genetically obese mouse. Endocrinology 107: 671-676

39. Govoni S, Yang H-YT (1981) Sex differences in the content of Bendorphin and enkephalin-like peptides of obese $(\mathrm{ob} / \mathrm{ob})$ mice. $\mathrm{J}$ Neurochem 36: 1829-1833

40. Ferguson-Segall M, Flynn JJ, Walker J, Margules DL (1982) Increased immunoreactive dynorphin and leu-enkephalin in posterior pituitary of obese mice (ob/ob) and super-sensitivity to drugs that act as kappa receptors. Life Sci 31: 2233-2236

41. Recant L, Voyles NR, Timmers KI, Awoke S, Bhathena SJ, Wells M (1984) Tissue opiate levels in hyper- and hypo-insulinaemic animal models. In: Fraioli F, Isidori A, Mazzetti M (eds) Opioid peptides in the periphery. Elsevier, Amsterdam, pp 271-281

42. Recant L, Voyles NR, Luciano M, Pert CB (1980) Naltrexone reduces weight gain alters "B endorphin" and reduces insulin output from pancreatic islets of genetically obese mice. Peptides 1 : 303-313

43. Flatt PR, Bailey CJ, Kwasowski P, Page T, Marks V (1984) Plasma immunoreactive gastric inhibitory polypeptide in obese hyperglycaemic (ob/ob) mice. J Endocrinol 101: 249-256

44. Flatt PR, Bailey CJ, Swanston-Flatt SK, Best L, Kwasowski P, Buchanan KD, Marks V (1984) Involvement of glucagon and GIP in the metabolic abnormalities of obese hyperglycaemic (ob/ob) mice. In: Shafrir E, Renold AE (eds) Lessons from animal diabetes. John Libbey, London, pp 341-347

45. Flatt PR, Bailey CJ, Kwasowski P, Swanston-Flatt SK, Marks V (1983) Abnormalities of GIP in spontaneous syndromes of obesity and diabetes in mice. Diabetes 32: 433-435

46. Recant L (1984) Discussion: relation of obesity and diabetes. In: Shafrir E, Renold AE (eds) Lessons from animal diabetes. John Libbey, London, pp 176-178

47. Flatt PR, Bailey CJ (1981) Development of glucose intolerance and impaired plasma insulin response to glucose in obese hyperglycaemic (ob/ob) mice. Horm Metabol Res 13: 556-560

48. Hughes J (1983) Biogenesis, release and inactivation of enkephaline and dynorphins. Br Med Bull 39: 17-24

Received: 14 July 1986

and in revised form: 26 November 1986

Dr. C.J. Bailey

Department of Molecular Sciences

Aston University

Birmingham B4 7ET

UK 